\title{
Giovanni Jacobo Gasparini kéziratos térképének szerkezete
}

Absztrakt: Magyarországról, illetve annak részeirôl 1528 után készült nyomtatott, vagy kéziratos térképek valamely korábban készült mü alapján születhettek meg. A térképek szerkezeti vizsgálata segítségünkre lehet annak eldöntésében, hogy egy adott mú „,kinek az egyenes ági, vagy oldalági” leszármazottja. Az általunk vizsgált Gasparini szerkesztette térkép szerkezete rokoni kapcsolatot mutat az 1566-ban megjelent Zsámboky János által készített és közreadott, és elsố alkalommal 1528-ban Ingolstadtban napvilágot látott Tabula Hungarie térképpel. Azt is megállapithatjuk, hogy Gasparini térképének topográfiai tartalmára Zsámboky e müve hatást nem gyakorolt. Ha alaposan nem vizsgáltuk volna meg Gasparini térképének szerkezetét, akkor a véleményünk továbbra is csak az lehetett volna, hogy e münek nincs kapcsolata más Magyarországot ábrázoló mappával.

Abstract: Printed or manuscripts maps of Hungary or parts of the country published after 1528 could all be made after works published earlier. The examination of the structure of these maps can help us determine theirfirst or secondary source map. The examination of the structure of Gasparini's map reveals its relationship with the Tabula Hungarie, the map prepared and published by Johannes Sambucus in 1566, which map was first published in Ingolstadt in 1528. It can also be stated that the topographic content of Gasparini's work lacks any influence of Sambucus' map. If we had not studied the structure of Gasparini's map carefully, we would have continued to hold the opinion that this work has no relationship with any map showing Hungary.

Kulcsszavak: Gasparini, szerkezetvizsgálat, Tabula Hungarie, Zsámboky János Keywords: Gasparini, structural examination, Tabula Hungarie, Johannes Sambucus

Pálffy Géza (1971-) történész kutatásai során Bécsben több olyan kéziratos térképet is talált, amelyek egykor a 16. századi magyarországi határvédelem megszervezéséhez készültek. E tanulmány Giovanni Jacobo Gasparini (15...-1595?) itáliai hadmérnök cím nélküli és keleti tájolású térképének szerkezetével kíván részletesebben foglalkozni.

\section{A térkép készítésének okai és előzményei röviden}

Szigetvár 1566. szeptember 7-i eleste után a Dunántúlból további jelentôs térség került a hódítók kezére, míg a magyar király joghatósága alá tartozó területek pedig zsugorodtak. Ezért a Dráva mentén - Szigetvártól nyugatra - az új országhatár védelmére Kanizsa térségében új végvárat kellett építeni. Végül Drinápolyban az egymással addig hadban álló felek képviselôi, II. (Iszákos) Szelim (1524-1574) szultán és I. Miksa (1527-1576) magyar király követei békét kötöttek, amelyet 1568. február 18-án írtak alá. A béke aláirásával magyar szempontból igen nehéz és fájdalmas korszak zárult le, de a jövô sem túnhetett biztatónak. Ugyan a szultán a békét követően majd negyedszázadig nem küldött hódító sereget Magyarországra, de a több száz kilométer hosszúságú „virtuális" határvidéken nem volt, nem is lehetett fegyvernyugvás, miközben a határsáv két oldalán élők folyamatosan fenyegetettségben élték mindennapjaikat (Czigány 2018). A magyarországi hódoltsági területeken ezért a drinápolyi béke, illetve annak különbözó idejú megerôsítései ellenére is szinte folyamatos volt a fegyverzaj. Ennek tulajdonképpen az volt az oka, hogy a hivatalos béke után hazánk hódoltsági területein a várakban állandóan állomásozó katonák szolgálataikért nem, vagy csak részben kaptak fizetséget. Másrészt azok a magas rangú katonák, akik szolgálataikért a szultántól ugyan más térségben javadalombirtokot kaptak, de folyamatosan magyarországi álláshelyeiken kellett tartózkodniuk, a birtokaikból származó jövedelmeikhez gyakran csak nehézségek árán juthattak. Így lényegében hazánkban a hódoltsági területeken élô török katonák jövedelemhez gyakorta csak zsákmányszerzó hadjáratok útján juthattak, ezért azok az idôk során mind gyakoribbakká is váltak. Például 1587-ben a Dunántúl déli részén lévô török helyôrségek parancsnokai Letenye és Alsólendva vidéke ellen indítottak támadást zsákmányszerzô céllal. A veszélyrôl gróf Zrínyi György (1549? -1626) horvát bán még idôben értesült, és e hírt továbbította Batthyány Boldizsár (1543? -1590) tábornoknak. Ezért, akik e térség békéjének megvédésért is felelősek voltak, összefogva, felkészülten várták az ellenséget. Gelse és Kacorlak között sikeresen csapdába csalták a magyar királyság területére betörố ellenséget, és felettük fényes gyôzelmet arattak. ${ }^{1}$

Az Oszmán Birodalom ugyanis 1578 tól 1590-ig a legfontosabb háborúját nem Európában, hanem Perzsiával vívta. A fentiek fényében már érthetô, hogy a törökök Budán miért ünnepelték meg a Perzsia ellen vívott hosszú háborút lezáró békét, mivel megérezték, hogy előttük a további hódításokra Európában új lehetôségek nyílnak meg. A 16. század utolsó évtizedében - még a béke ideje alatt - a boszniai és a horvátországi területekrôl egyre gyakrabban indultak zsákmányszerző hadjáratok Szlovénia, Horvátország és rajtuk keresztül az osztrák örökös tartományok irányába is a Porta hallgatólagosan engedélyével, amelyek 1591-tôl

\footnotetext{
1 http://gyorkos.uw.hu/1567-1592/1567$\underline{1592 . \mathrm{htm}}$
} 
szinte állandósultak. A korábbi békés éveknek végül hivatalosan III. Murád (1546-1595) szultán 1593. július 4-i hadüzenete vetett véget. 1593-ban már dunántúli, illetve felföldi várak visszafoglalására is sor került, illetve a hódítókkal szemben a magyarok és a szövetségeseik eredményes mezei ütközeteket is vívtak.

Gasparini végvárvonaltérképének keletkezési idejét Pálffy a hadi eseményekre utaló jelölések, illetve a készítôre vonatkozó korabeli bejegyzések alapján 1594-re tette (Pálffy 2000). ${ }^{2}$ E szóban forgó térkép három végvidéki fôkapitányság, a kanizsai, a gyôri és a bányavidéki területét ábrázolta. E térkép megtalálója könyvében Gasparini múvérôl a következôket vetette papírra: „Noha összeállítója és megrajzolója nem volt «hivatásos térképész», a kor nyomtatott mappái közül néhányat bizonyosan látott és ismert, sôt igyekezett azok díszítő elemeinek egy részét átvenni vagy legalább utánozni, bár munkája alapvetôen katonai célokat szolgált." (Pálffy 2000) Gasparini térképe keleti tájolású „azaz a térkép legalján található bécsi császárvárosból szemlélve ábrázolta a szóban forgó területet. (...) A térkép ugyanis Európa szemszögéból és a bécsi hadvezetés szemüvegén át ábrázolta a «kereszténység védőbástyájának szerepét két évszázadon át betöltő törökellenes magyarországi védelmi rendszert»." (Pálffy 2000)

\section{A térképek közötti kapcsolatok vizsgálata}

Vajon szerkezetvizsgálati módszerrel megismerhetô-e az, hogy valamely Magyarországot, vagy annak csak egy részét ábrázoló mappának egykor milyen térképi forrása lehetett?

„A térkép - ahogy azt Günther Hake (1918-1995) igen pontosan megfogalmazta - a térbeli vonatkozások mértékhez kötött és rendezett modellje.” Míg a Nemzetközi Térképészeti Társulás (ICA) 1995-ben a térképet a következőképpen definiálta: „a térkép a földrajzi valóság szimbolizált megjelenése, amely tetszés szerint kiválasztott

\footnotetext{
2 Az e tanulmányban szereplố térképrészletek a Pállfy Géza könyvéhez készült fakszimile térkép részletei.
}

elemeket elsôsorban a térbeli kapcsolatok szemléltetése érdekében ábrázolja." (Klinghammer 2010)

A fenti megfogalmazások nemcsak jelen korunkra igazak, de a múltban készült térképekre is, azzal a nyilvánvaló korláttal, hogy e mûvek vizsgálatánál figyelemmel kell lennünk azok keletkezésének idején a készítôk rendelkezésére álló technikai és technológiai lehetőségekre, azaz e mappákkal szemben ne állítsuk azokat a követelményeket, amelyeket 20. századi térképek (geodéziai, topográfiai és áttekintô stb.) esetén joggal elvárunk.

A térképek közötti kapcsolatok vizsgálhatók

- a térképek szerkezete

- és topográfiai tartalma alapján.

\section{A térképek szerkezetének vizsgálata}

A térinformációs rendszerek létrehozása során merült fel elôször arra igény, hogy eltérố vonatkozási, illetve vetületi rendszerben keletkezett különbözô térbeli adatok egyetlen rendszerre vonatkoztatva legyenek rögzítve. A különböző vonatkozási rendszerekhez tartozó síkkordináták közötti átszámítás transzformációs egyenletek felhasználásával történhet. A transzformációs egyenletek két leggyakoribb fajtája a következő:

- síkbeli hasonlósági transzformáció,

- affin transzformáció (DetrekóiSzabó 2002).

Kutatásaink alapján a régi térképek szerkezetének vizsgálatára a hasonlósági, vagy Helmert-transzformáció bizonyult a legalkalmasabbnak oly módon, hogy a régi térképek esetén csak a geometriai alakzatot és azok irányát vizsgáljuk. A térképeken minden esetben azonos, általunk kiválasztott négy térbeli pontot összekötố vonalak által kijelölt terület alakját és elfordulását hasonlítottuk össze. Így is elegendô információt kaphatunk arról, hogy az általunk vizsgált térképrészletek között van-e bármilyen kapcsolat. Modern térképpel való összevetéssel pedig még választ kaphattunk arra kérdésünkre is, hogy a vizsgált mú milyen mértékben tükrözte a terület valós topográfiáját (Plihál 2013).

Az általunk kifejlesztett és használt szerkezetvizsgálati módszerünkkel megvizsgáljuk Gasparini térképét. ${ }^{3}$ Gasparini is csak úgy kezdhette el kéziratos térképének megrajzolását, hogy a rendelkezésére álló forrásról olyan térbeli pontok (település, vár) helyét vette át, amelybe utóbb az általa választott méretaránynak megfelelốen el tudja helyezni a további hozzáadott topográfiai tartalmat. Nézzük meg, hogy e térképének részletei mirôl is árulkodnak.

Az ábrákon az érintett településeket minden részleten piros pontok jelölik. A fekete keretes részlet a Tabula Hungariae-rôl (1 : 1080 000, Ingolstadt, 1528), a szürke színnel kitöltött részlet Gasparini térképérôl való, és mindkét részlet északi irányba lett beforgatva. A piros keretes részlet W. Lazius Magyarország-térképe szerinti (1 : 540 000, Bázel, 1556).

Az elsố részlet vizsgálata alapján megállapíthattuk azt, hogy a Tabula Hungariae térképtôl való eltérés mértéke körülbelül 8\%. Amikor a vizsgált részletet Lazius 1556-ban megjelent térképének megfelelố részletével hasonlítottuk össze, akkor az alakban és az irányban való eltérés már meghaladta 30\%-ot, így véleményünk szerint Gasparini a térképe szerkesztésénél Laziust múvét forrásként aligha használhatta. (A részletek összehasonlítása során abszolút számok helyett az eltérések értékét \%-ban adtam meg azért, mert a vizsgált területek valós nagysága igen eltérô. A szögeket eredeti méretben kinyomtatott részleteken mértem meg, és azt számítottam át \%-ra azért, hogy a képeken is látható különbségek mértékérôl az olvasó összevethetố adatok birtokába juthasson.)

A második és a harmadik ábrán látott részletek alakjai és irányai 2\%-nál kisebb mértékben tértek el az általunk azonosított forrástérképtôl. Gasparini gyaníthatóan a Tabula Hungariae térkép 1566-os Zsámbokyféle kiadását használhatta, mivel az Bécsben, a Haditanács tárgyalótermében falitérképként is ki volt függesztve. Ez egyben arra is utal, hogy Gasparini ismerte az általa használt forrástérkép helyes tájolását, majd az

\footnotetext{
3 Mérete $57 \times 43 \mathrm{~cm}$. Lelôhelye Österreichisches Staatsarchiv, Wien. Haus-, Hof- und Staatsarchiv, Kartensammlung U/II/4/8.
} 


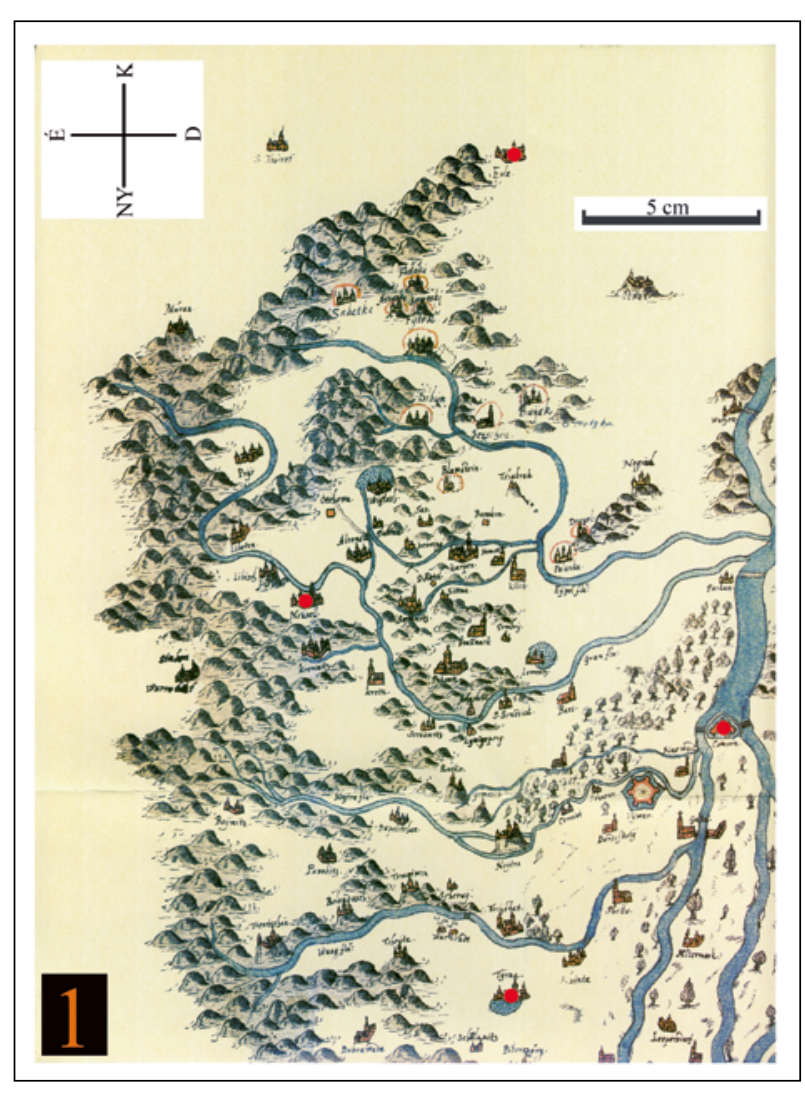

Komárom és környéke

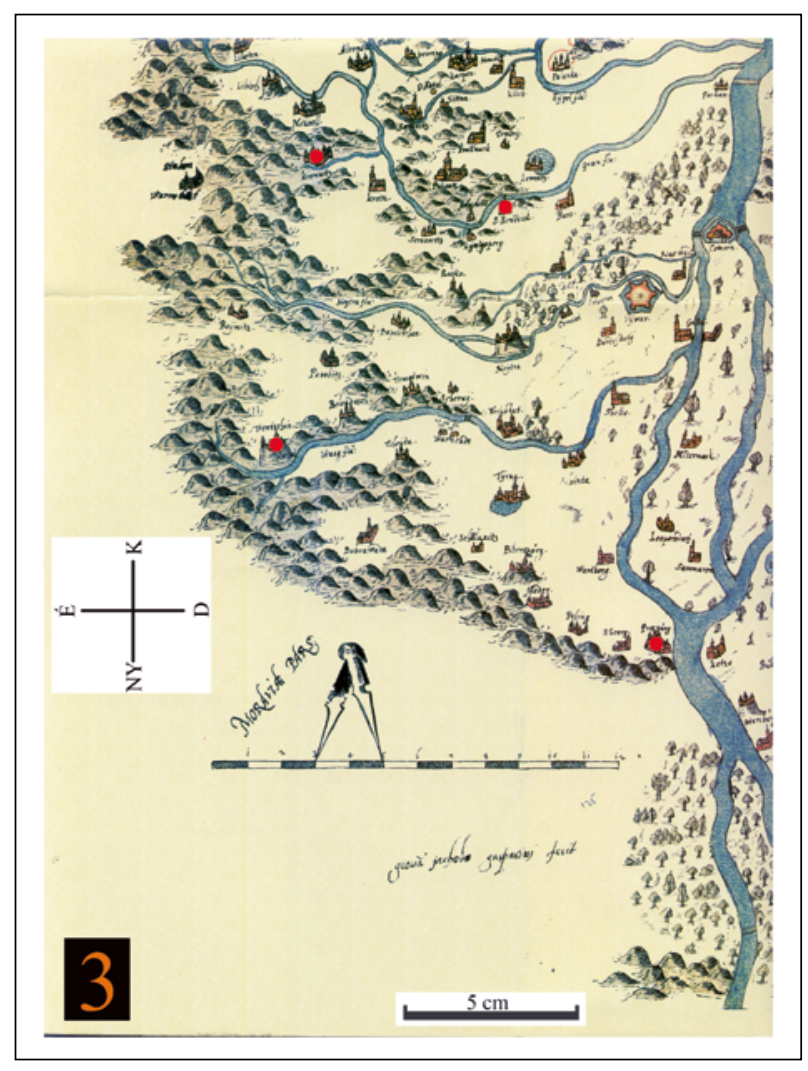

Pozsony és környéke

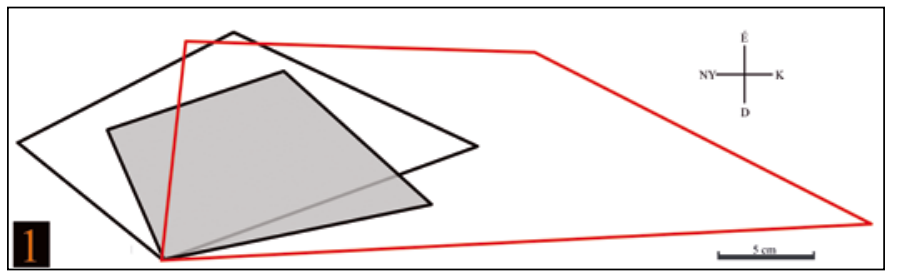

1. ábra. Komárom-Nagyszombat-Besztercebánya-Eger településekkel határolt terület alakja és iránya

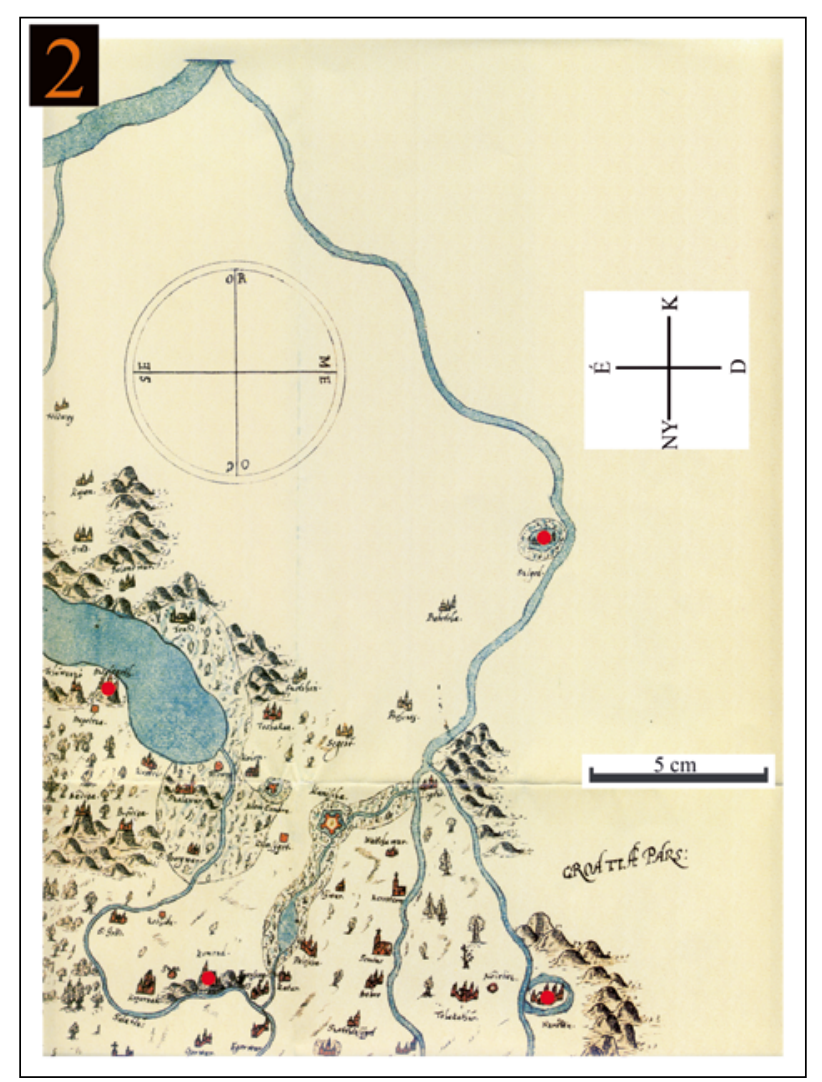

Varasd és környéke

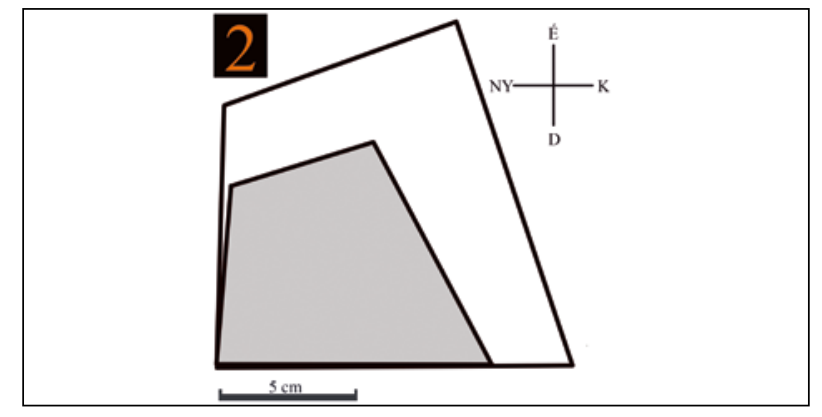

2. ábra. Varasd-Szigetvár-Szigliget-Körmend településekkel határolt terület alakja és iránya

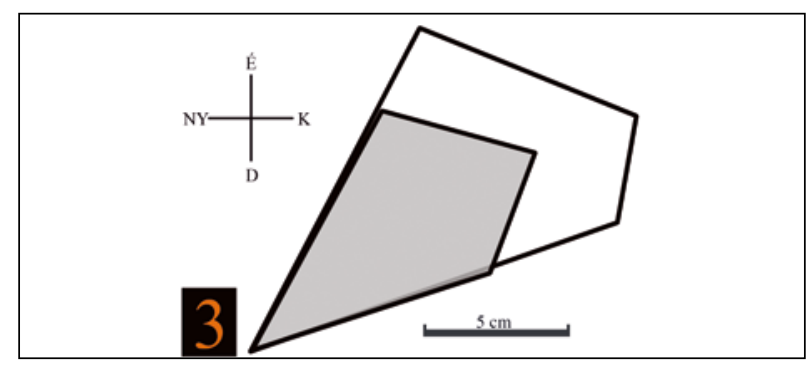

3. ábra. Pozsony-Trencsén-Körmöcbány Garamszentbenedek településekkel határolt terület alakja és iránya 


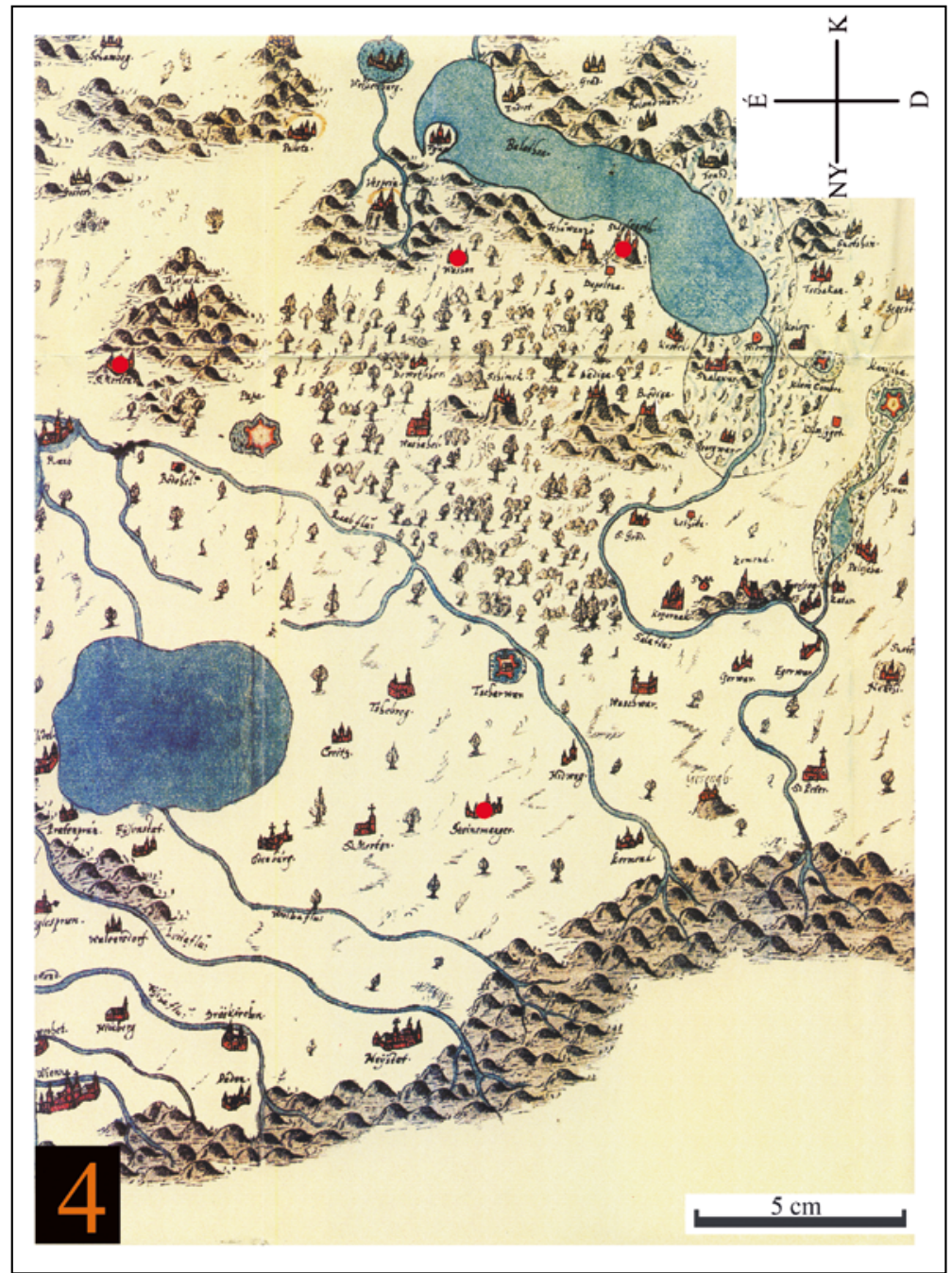

Szombathely és környéke

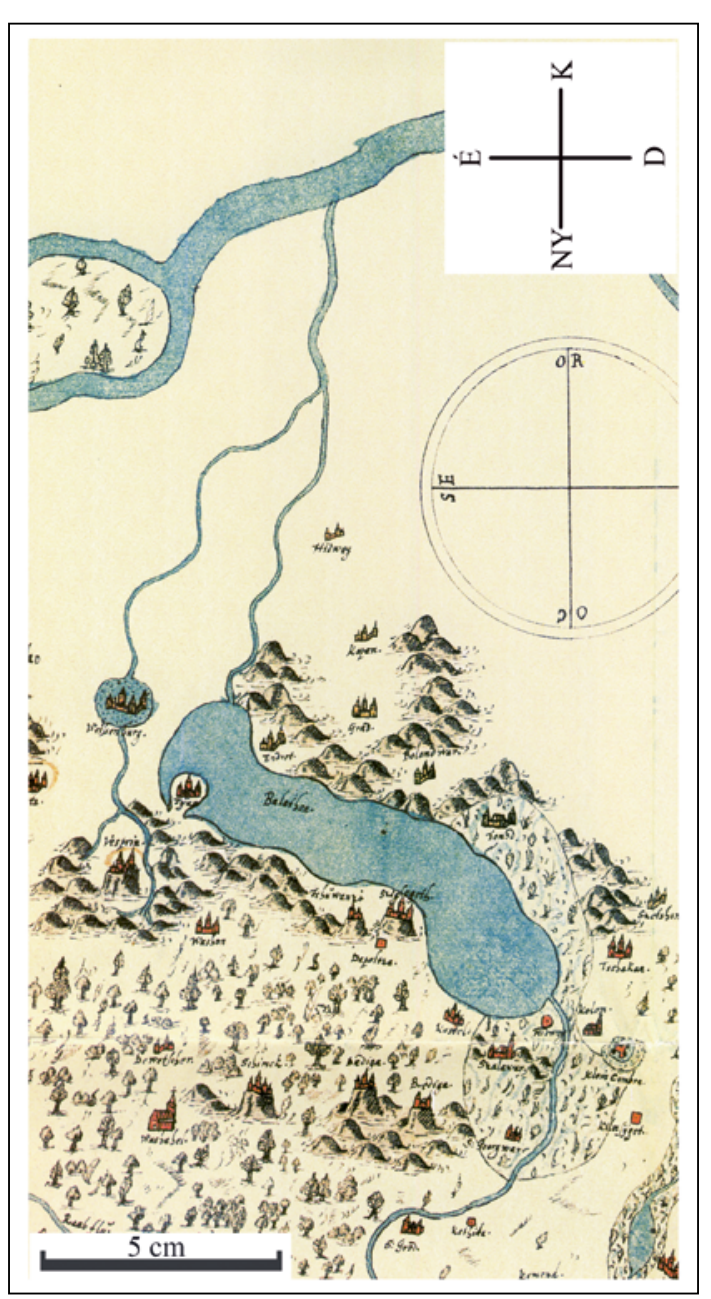

5. ábra. A Balaton és környéke Gasparini térképén

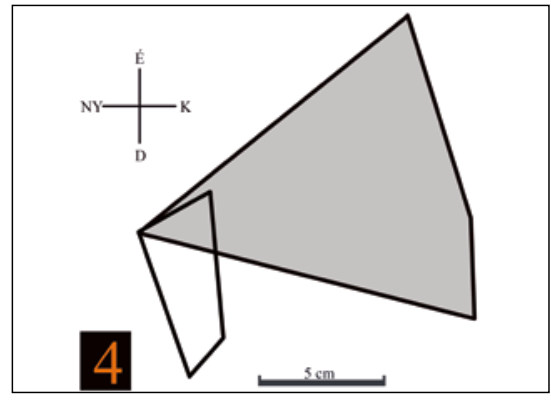

4. ábra. Szombathely-PannonhalmaNagyvázsony-Szigliget településekkel határolt terület alakja és iránya

onnan levett adatokat a saját, keleti tájolású térképébe átszerkesztve pontosan behelyezte. Ugyanakkor nem tudjuk megmondani azt, hogy a munkája kezdetén Zsámboky szóban forgó térképérôl hány település helyét emelete át. A részletek összehasonlítása után azt is meg tudtuk határozni, hogy Gasparini térképe kb. $1: 1200$ 000-es ${ }^{4}$ méretarányú lehetett.

\footnotetext{
${ }^{4}$ Korábban a térkép méretarányát kb. 1 : 720 000-re tették (Pálffy 2000).
}

Ez utóbbi részlet alakjában és irányában teljes egészében különbözik az általunk forrásként azonosított térképtôl. E részlete alapján az is jól látszik, hogy Gasparini az általa hozzáadott települések és várak közötti távolságokról és azok egymáshoz való viszonyairól csak hozzávetôleges adatokkal rendelkezett.

A fenti vizsgálataink alapján arra is fény derült, hogy beosztásából eredôen ố a Felföld területét jobban ismerte, ismerhette, mint például a Dráva mentét.

\section{A topográfia tartalom vizsgálata}

\section{A földrajzi nevek írása.}

A térképen 183 hely- és várnév (Pálffy 2000) található, korabeli németes helyesírással. Sajnos a helynevek írása alapján Gasparini lehetséges forrását vagy forrásait a Magyarországot ábrázoló nyomtatott térképekrôl készített helynévadatbázisunkban nem tudtuk azonosítani.

\section{A vízhálózat ábrázolása.}

E mappán szerepelt elsô alkalommal a Séd, a Sárvíz és a Sió vízrendszere helyesen. A Zala folyót is részben helyesen ábrázolta, az Hidvégnél ${ }^{5}$ ömlött a Balatonba (5. ábra).

Gasparini is rögzítette azt a helyzetet, hogy esetenként, csapadékos időben a Kanizsa-patakon keresztül a Zalának volt vízrajzi kapcsolat a Mura folyóval is (Kelenik 1995). Más részrôl a Fertố tavat és a Hanságot együtt ábrázolta, s a térkép szerint az egyik Rába (helyesen Rábca) folyó azon keresztül jutott el a Dunába, ahogy arról már Johannes Cuspinian (14731529) munkájából korábban is értesülhettünk. Ugyanakkor ábrázolta

$$
5 \text { Ma Zalavár része. }
$$



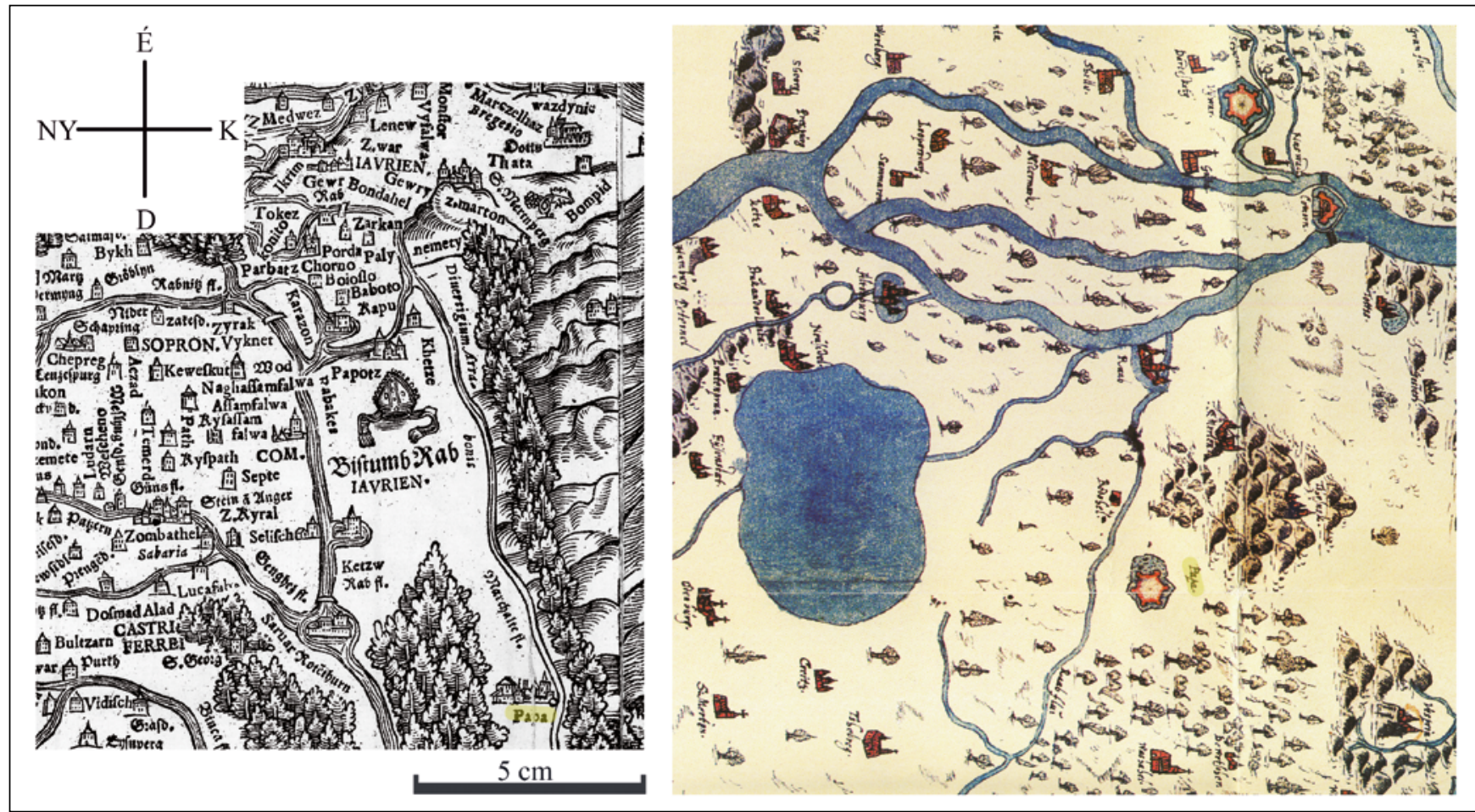

6. ábra. A Fertő tó és környéke Lazius és Gasparini térképein

azt a Rába folyót is, amely Gyốrnél érte el a Dunát ${ }^{6}$, bár e folyó nyomvonala, ahogy a 6 . ábrán is látható, a Fertố magasságában furcsa módon „megszakadt”.

A Rábával egy ideig párhuzamosan futó Marcal folyó Gasparini térképén szintén Rába névvel tû́nik fel. Míg Pápa várát Lazius térképe a Marcal folyótól nyugatra, addig Gasparini helyesen, attól keletre ábrázolta. A felföldi folyók, a Vág, a Nyitra, a Zsitva, a Garam és az Ipoly ábrázolásai topográfiailag sokkal helyesebbek. Gyaníthatóan a Gasparini térképén látható gazdag folyóhálózat forrása is valamely, a hadmérnökök által készített kéziratos térkép lehetett.

\footnotetext{
${ }^{6}$ Itt (ti. Győrnél) egy másik folyó is beleömlik a Dunába, csaknem ugyanazon az útvonalon, nem messze a Rábától. Ezt a folyót Rebnitznek nevezik. Kirchschlag közelében ered, ahol két róla elnevezett falu is található, Felsốrámóc (Oberrabnitz) és Alsórámóc (Unterrabnitz). Ezután ez is keresztülfolyik a Fertôn, amelynek hosszúsága hét mérföld szélessége pedig három mérföld, miként azt világosan láthatjuk a mi Magyarország térképünkön, amelyet királyunknak aján lottam fel. Az említett két folyó népes és termékeny szigetet alkot, amelyet „Rabauu”nak (Rabaw?) neveznek. - In Plihál Katalin: Tabula Hungariae ... Ingolstadt, 1528. térkép és utóélete. Az eddigi és a jelenlegi kutatások tükrében. Budapest, 2013. pp. 166
}

A domborzat ábrázolása.

Gasparini szerint - ahogy azt az 5. ábrán bemutatott részleten is láthatjuk - a Balaton déli partja mentén a Sió folyótól Fonyódig terjedô területen magasabb hegyek voltak.

\section{Összefoglalás}

A szerkezeti vizsgálataink eredményei meggyôzốen visszaigazolták módszerünk használhatóságát még olyan térképek esetén is, ahol a forrás vagy a források keresése látszólag felesleges erôfeszítésnek túnhet.

Ahogy a fenti példáink is igazolják, a topográfiai tartalom vizsgálata e kéziratos térkép kapcsolatainak megismerésében sajnos segítséget nem jelentett. Értelemszerúen a hadmérnökök által jobban ismert dunántúli területekrôl készített térképeknek a topográfiai tartalma sokkal pontosabb volt, mint a Magyarországról abban az idôben nyomtatásban megjelenteké lehetett. Azt is megállapíthatjuk, hogy a topográfiai tartalomra az 1566-ban Zsámboky készítette Tabula Hungariae térkép nem gyakorolt hatást.

Ha alaposan nem vizsgáltuk volna meg Gasparini térképének szerkezetét, akkor a véleményünk továbbra is csak az lehetett volna, hogy e múnek nincs kapcsolata más Magyarországot ábrázoló mappával.

\section{Irodalom}

Czigány István 2018. A „nyitott határ” - egy hadtörténelmi paradoxon hatása. Néhány gondolat a Magyar Királyság oszmánellenes védelmi rendszerének sajátosságairól, Aetas 33. évf. 4. sz. pp. 73-77.

Detrekối Ákos - Szabó György 2002. Térinformatika, Nemzeti Tankönyvkiadó, Budapest, pp. 80-82.

Kelenik József 1995. A kanizsai védelmi övezet és természetföldrajzi adottságai. In Végvár és környezet. Studia Agriensis 15. Eger, pp. 168-169.

Klinghammer István (szerk.) 2010. Térképészet és geoinformatika I., Eötvös Kiadó, Budapest, p. 103.

Pálffy Géza 2000. Európa védelmében. Haditérképészet a Habsburg Birodalom magyarországi határvidékén a 16-17. században. Második, javított és bóvített kiadás, Pápa, pp. 77-88., 93-112

Plihál Katalin 2013. A Tabula Hungariae... Ingolstadt, 1528. térkép és utóélete. Az eddigi és a jelenlegi kutatások tükrében. OSZK - Kossuth Kiadó, Budapest, pp. 59-74.

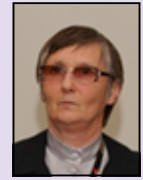

Dr. Plihál Katalin térképtörténész

plihal1948@gmail.com 